\title{
Preparation, Structure, Photoluminescent and Semiconductive Properties, and Theoretical Calculation of a Novel Cadmium Complex with Mixed Ligands
}

\author{
Xiu-Guang Yi, ${ }^{1,2}$ Wen-Tong Chen, ${ }^{1,3,4, \star}$ Jian-Gen Huang, ${ }^{1}$ Ding-Wa Zhang ${ }^{1}$ \\ and Yin-Feng Wang ${ }^{1}$ \\ ${ }^{1}$ Institute of Applied Chemistry, Jiangxi Province Key Laboratory of Coordination Chemistry, School of Chemistry \\ and Chemical Engineering, Jinggangshan University, Jian, Jiangxi, 343009, China \\ ${ }^{2}$ Research Center for Rare Earths \& Nano/micro Functional Materials, \\ Nanchang University Nanchang, Jiangxi 330031, China \\ ${ }^{3}$ Key Laboratory of Jiangxi Province for Persistant Pollutants Control and Resources Recycle \\ (Nanchang Hangkong University), Nanchang, Jiangxi 330000, China \\ ${ }^{4}$ State Key Laboratory of Structural Chemistry, Fujian Institute of Research on the Structure of Matter, \\ Chinese Academy of Sciences, Fuzhou, Fujian 350002, China \\ *Corresponding author: E-mail: wtchen_2000@aliyun.com \\ Tel.: +86(796)8100490; fax +86(796)8100490
}

Received: 18-09-2017

\begin{abstract}
A novel cadmium complex with mixed ligands $\left\{\left[\mathrm{Cd}\left(2,2^{\prime} \text {-biim }\right)\left(4,4^{\prime} \text {-bipy }\right)\left(\mathrm{H}_{2} \mathrm{O}\right)\left(\mathrm{ClO}_{4}\right)\right]\left(\mathrm{ClO}_{4}\right)\right\}_{\mathrm{n}}(\mathbf{1})\left(2,2^{\prime}\right.$-biim $=$ 2,2'-biimidazole; 4,4'-bipy $=4,4$ '-bipyridine) has been synthesized through hydrothermal reaction and its crystal structure was determined by single-crystal X-ray diffraction technique. Single-crystal X-ray diffraction analyses revealed that complex 1 crystallizes in the space group Pna $2_{1}$ of the orthorhombic system and exhibits a one-dimensional zigzag chain structure consisting of $\left[\mathrm{Cd}\left(2,2^{\prime} \text {-biim }\right)\left(4,4^{\prime} \text {-bipy }\right)\left(\mathrm{H}_{2} \mathrm{O}\right)\left(\mathrm{ClO}_{4}\right)\right]_{n}{ }^{n+}$ cationic chains and isolated $\mathrm{ClO}_{4}^{-}$anions. Powder photoluminescent characterization reveals that complex 1 has an emission in the green region of the spectrum. Time-dependent density functional theory (TDDFT) calculation showed that the nature of the photoluminescence of complex 1 is originated from the ligand-to-ligand charge transfer (LLCT; from the HOMO of the perchlorate anions to the LUMO of the 4,4'-bipy ligand). A wide optical band gap of $3.25 \mathrm{eV}$ was found by the solid-state UV/vis diffuse reflectance spectrum.
\end{abstract}

Keywords: Cadmium, photoluminescence, semiconductor, TDDFT, LLCT

\section{Introduction}

In recent years, preparation and characterization of coordination complexes have attracted increasing interest not only due to their amazing structural topologies but also their potential applications in the fields of catalyst, sensors, medicine, biology, solar energy conversion, magnetism, photoluminescence materials, and so forth. ${ }^{1-, 5}$ From the perspective of the crystal engineering, the most useful and facile way to construct coordination complexes is to adopt a suitable ligand to connect metal centers. To this end, the ligand is better to possess as much as donor atoms that enable it to bridge metal centers together to yield extended architectures. $\mathrm{N}$-containing heterocyclic ligands (e.g., 2,2'-biim and 4,4'-bipy namely, 2,2'-biimidazole and 4,4'-bipyridine, respectively), which have several coordination sites and various coordination modes, have been widely applied as such ligands to design novel coordination complexes. ${ }^{6-12} 2,2^{\prime}$-biim and 4,4'-bipy have been confirmed to be a good chelating or bridging ligand to build coordination complexes. Being very strong N-ligating ligands, 2,2'-biim and 4,4'-bipy are also important to 
afford useful supramolecular recognition positions to form interesting supramolecular topologies. Therefore, 2,2'-biim and 4,4'-bipy are important and useful ligands to achieve extended structures or supramolecular geometries. Furthermore, the imidazole or pyridyl rings of the 2,2'-biim or 4,4'-bipy possess delocalized $\pi$-electron systems which allow them to become an ideal candidate to prepare photoluminescent materials.

In addition, coordination complexes possessing group 12 (IIB) elements ( $\mathrm{Zn}, \mathrm{Cd}, \mathrm{Hg}$ ) are attractive due to their photoluminescent and semiconductive properties, various coordination numbers and topologies provided by their $\mathrm{d}^{10}$ configuration of the IIB ions, as well as the important role of zinc played in biological systems. ${ }^{13-15}$ For the sake of exploring the metal ions on the structures and properties of the coordination complexes, we often choose the IIB ions as the central ion source. In order to explore novel IIB coordination complexes with attractive structural topologies and interesting properties, we recently focus on the design and preparation of novel IIB coordination complexes with various organic ligands. We report in this work the preparation, crystal structure, photoluminescent and semiconductive properties, and theoretical calculation of a novel cadmium complex with mixed ligands, i.e. $\left\{\left[\mathrm{Cd}\left(2,2^{\prime} \text {-biim }\right)\left(4,4^{\prime} \text {-bipy }\right)\left(\mathrm{H}_{2} \mathrm{O}\right)\left(\mathrm{ClO}_{4}\right)\right]\left(\mathrm{ClO}_{4}\right)\right\}_{\mathrm{n}}$ (1) with a 1-D zigzag chain structure. It should be pointed out that this is the first IIB complex with both 4,4'-bipy and 2,2'biim ligands.

\section{Experimental}

\section{1. Materials and Instrumentation.}

All chemicals and reagents were of reagent grade, commercially available and directly applied for the reaction. Photoluminescent characterization was measured using solid-state powders of the title complex at room temperature on a JY FluoroMax-3 spectrometer. Time-dependent density functional theory (TDDFT) calculation was performed by virtue of the Gaussian03 suite of program packages. Solid-state UV/vis diffuse reflectance measurement was conducted on a computer-controlled TU1901 $\mathrm{UV} /$ vis spectrometer equipped with an integrating sphere attachment. Finely-ground powder sample was coated on barium sulfate which acts as a reference for $100 \%$ reflectance.

\section{2. Synthesis of $\left\{\left[\mathrm{Cd}\left(2,2^{\prime}\right.\right.\right.$-biim $)\left(4,4^{\prime}\right.$-bipy $)$ $\left.\left.\left(\mathrm{H}_{2} \mathrm{O}\right)\left(\mathrm{ClO}_{4}\right)\right]\left(\mathrm{ClO}_{4}\right)\right\}_{\mathrm{n}}(\mathbf{1})$}

$\mathrm{Cd}\left(\mathrm{ClO}_{4}\right)_{2} \cdot 6 \mathrm{H}_{2} \mathrm{O}(1.00 \mathrm{mmol}, 0.420 \mathrm{~g}), 2,2$ '-biim (1.00 $\mathrm{mmol}, 0.134 \mathrm{~g}), 4,4^{\prime}$-bipy $(1.00 \mathrm{mmol}, 0.156 \mathrm{~g})$ and $10 \mathrm{~mL}$ distilled water were put into a $25 \mathrm{~mL}$ vial of a Teflon-lined stainless steel autoclave. The autoclave was heated around $433 \mathrm{~K}$ under autogenous pressure over a period of ten days and powered off, then cooled to room temperature. Finally, light-yellow block crystals were collected, washed with dis- tilled water, dried in air and used for single-crystal X-ray diffraction as well as property measurements. The yield was 24\% (based on cadmium). Caution: perchlorate salts are highly explosive and must be handled with careful!

\section{3. X-ray Structure Determination}

The single-crystal data of the title complex were collected on a SuperNova X-ray diffractometer equipped with a graphite monochromated Mo-Ka radiation source $(\lambda=$ $0.71073 \AA$ ) at $293(2) \mathrm{K}$. The diffraction was performed by means of a $\omega$ scan mode. Using the CrystalClear software, we reduced the data set and corrected the empirical absorption. ${ }^{16}$ The crystal structure was successfully solved by using the direct methods and Siemens SHELXTLTM Version 5 software package. ${ }^{17}$ The non-hydrogen atoms were generated based on the subsequent Fourier difference maps and refined anisotropically. The hydrogen atoms were located theoretically and ride on their parent atoms;

Table 1. Crystallographic data and structural analysis for complex 1

\begin{tabular}{ll}
\hline Formula & $\mathbf{C}_{\mathbf{1 6}} \mathbf{H}_{\mathbf{1 6}} \mathbf{C d C l}_{\mathbf{2}} \mathbf{N}_{\mathbf{6}} \mathbf{O}_{\mathbf{9}}$ \\
\hline$M_{\mathrm{r}}$ & 619.65 \\
Crystal system & orthorhombic \\
Space group & $P n a 2_{1}$ \\
$a(\AA)$ & $17.7584(5)$ \\
$b(\AA)$ & $9.8785(3)$ \\
$c(\AA)$ & $12.3847(4)$ \\
$V\left(\AA^{3}\right)$ & $2172.60(11)$ \\
$Z$ & 4 \\
Reflections collected & 6691 \\
Independent, observed reflections $\left(R_{\text {int }}\right)$ & $3304,3118(0.0219)$ \\
$d_{\text {calcd. }}\left(\mathrm{g} / \mathrm{cm}^{3}\right)$ & 1.894 \\
$\mu / \mathrm{mm}^{-1}$ & 1.315 \\
$F(000)$ & 1232 \\
$R_{1}, w R_{2}$ & $0.0271,0.0634$ \\
$S$ & 1.027 \\
$\Delta \rho(\max , \min )\left(\mathrm{e} / \AA^{3}\right)$ & $0.388,-0.350$ \\
\hline
\end{tabular}

Table 2. Selected bond lengths $(\AA)$ and bond angles $\left({ }^{\circ}\right)$ for complex 1

\begin{tabular}{|c|c|c|c|}
\hline Distance & $(\AA ̊)$ & Distance & $(\AA ̊)$ \\
\hline $\mathrm{Cd} 1-\mathrm{N} 5^{\mathrm{i}}$ & $2.290(3)$ & Cd1-N6 & $2.355(3)$ \\
\hline Cd1-O1W & $2.296(3)$ & $\mathrm{Cd} 1-\mathrm{N} 4$ & $2.369(4)$ \\
\hline $\mathrm{Cd} 1-\mathrm{N} 2$ & $2.303(3)$ & $\mathrm{Cd} 1-\mathrm{O} 7$ & $2.499(4)$ \\
\hline Angle & $\left({ }^{\circ}\right)$ & Angle & $\left({ }^{\circ}\right)$ \\
\hline $\mathrm{N} 55^{\mathrm{i}}-\mathrm{Cd} 1-\mathrm{O} 1 \mathrm{~W}$ & $95.24(14)$ & $\mathrm{N} 2-\mathrm{Cd} 1-\mathrm{N} 4$ & $72.89(11)$ \\
\hline $\mathrm{N} 5^{\mathrm{i}}-\mathrm{Cd} 1-\mathrm{N} 2$ & $170.58(14)$ & N6-Cd1-N4 & $91.18(13)$ \\
\hline N2-Cd1-O1W & $86.63(13)$ & $\mathrm{N} 5{ }^{\mathrm{i}-\mathrm{Cd} 1-\mathrm{O} 7}$ & $87.33(12)$ \\
\hline N6-Cd1-O1W & $99.57(13)$ & O1W-Cd1-O7 & $77.90(14)$ \\
\hline N2-Cd1-N6 & $99.89(12)$ & N2-Cd1-O7 & $84.04(12)$ \\
\hline 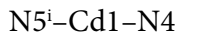 & $103.84(12)$ & N6-Cd1-O7 & $175.26(12)$ \\
\hline N4-Cd1-O1W & $158.28(12)$ & $\mathrm{N} 4-\mathrm{Cd} 1-\mathrm{O} 7$ & $92.53(14)$ \\
\hline
\end{tabular}

Symmetry code: (i) $-x-1 / 2, y+1 / 2, z-1 / 2$. 
however, the hydrogen atoms of the coordinated water molecule were not located and are not included into the model. The single-crystal structure was finally refined by using the full-matrix least-squares procedure on $F^{2}$. Crystallographic data and structural refinements for the title complex are summarized in Table 1 . Selected bond lengths and bond angles for the crystal structure are displayed in Table 2 . The hydrogen bonding interactions are presented in Table 3.

\section{Results and Discussion}

Single-crystal X-ray diffraction measurement revealed that complex 1 crystallizes in the space group Pna $2_{1}$ of the orthorhombic system with four formula units in one unit cell and the crystallographically asymmetric unit is comprised of one cadmium ion, one 4,4'-bipy ligand, one 2,2'-biim ligand, one isolated perchlorate anion, one coordinating perchlorate anion and one coordinating water molecule, as presented in Fig. 1. Complex $\mathbf{1}$ is characterized by a $1-\mathrm{D}$ zigzag chain structure, consisting of $\left[\mathrm{Cd}\left(2,2^{\prime}\right.\right.$ biim) $\left(4,4^{\prime}\right.$-bipy $\left.)\left(\mathrm{H}_{2} \mathrm{O}\right)\left(\mathrm{ClO}_{4}\right)\right]_{n}^{n+}$ cationic chains and isolated $\mathrm{ClO}_{4}^{-}$anions. The cadmium ion displays a slightly distorted octahedral geometry with the equatorial positions inhabited by three nitrogen atoms from one 2,2'-biim and one 4,4'-bipy ligand as well as one oxygen atom from one coordinating water molecule, and the apical sites are occupied by one oxygen atom from one coordinating perchlorate anion as well as one nitrogen atom from one 4,4'bipy ligand (Fig. 1).
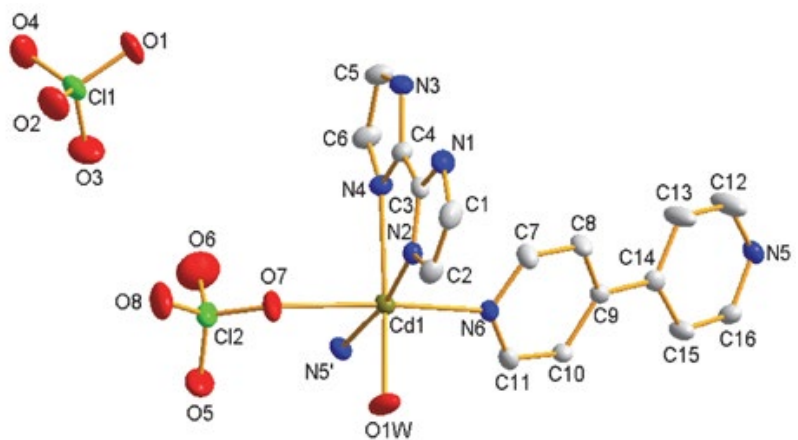

Figure 1. An ORTEP diagram of complex 1 with 30\% thermal ellipsoids. Hydrogen atoms are omitted for clarity. Symmetry code: $-x$ $-1 / 2, y+1 / 2, z-1 / 2$.

The neighboring cadmium ions are interconnected by the 4,4'-bipy ligands through the nitrogen atoms to construct a $1 \mathrm{D}$ zigzag chain structure running along the $b$-axis, as depicted in Fig. 2. Different from the bridging 4,4'-bipy ligand, the 2,2'-biim molecule acts as a terminal ligand and chelates to one cadmium ion with the chelating angle N2-Cd1-N4 being of $72.89(11)^{\circ}$. In complex $\mathbf{1}$, there are two kinds of perchlorate anions, namely, termi- nally coordinating and isolated. The Cd...Cd distance is 11.5886(2) $\AA$ because of the distraction of the long rodlike bridging 4,4'-bipy ligand. The bond lengths of $\mathrm{Cd}-\mathrm{N}$ are in the range of 2.290(3)-2.369(4) $\AA$ with a mean value of 2.329(4) $\AA$. This is in agreement with those found in the literature. ${ }^{18-20}$ The bond lengths of $\mathrm{Cd}-\mathrm{O}$ for water and for perchlorate ligand are 2.296(3) $\AA$ and 2.499(4) $\AA$, respectively. This is also comparable with those reported in the literature. ${ }^{21-24}$ The bond angle of $\mathrm{N} 5^{\prime}-\mathrm{Cd} 1-\mathrm{N} 2$ is $170.58(14)^{\circ}$, close to $180^{\circ}$, while other N-Cd-N angles locate in a range of $72.89(11)^{\circ}-103.84(12)^{\circ}$, close to $90^{\circ}$. The bond angles of N4-Cd1-O1W and N6-Cd1-O7 are $158.28(12)^{\circ}$ and $175.26(12)^{\circ}$, respectively, while other N$\mathrm{Cd}-\mathrm{O}$ angles are in a range of $84.04(12)^{\circ}-99.57(13)^{\circ}$. The bond angle of $\mathrm{O}-\mathrm{Cd}-\mathrm{O}$ is only $77.90(14)^{\circ}$. The dihedral angle of the pyridyl rings of the $4,4^{\prime}$-bipy ligand is $14.90(4)^{\circ}$. The imidazole rings of the $2,2^{\prime}$-biim ligand is nearly coplanar with a small dihedral angle of $4.64(2)^{\circ}$, which is close to that in another cadmium 2,2'-biim complex $\left(3.23^{\circ}\right) .{ }^{25} \mathrm{In}$ complex 1 , there are many hydrogen bonding interactions such as $\mathrm{N}-\mathrm{H} \ldots \mathrm{O}$ and $\mathrm{C}-\mathrm{H} \cdots \mathrm{O}$ interactions as listed in Table 3. The 1-D $\left[\mathrm{Cd}\left(2,2^{\prime} \text {-biim }\right)\left(4,4^{\prime} \text {-bipy }\right)\left(\mathrm{H}_{2} \mathrm{O}\right)\left(\mathrm{ClO}_{4}\right)\right]_{n}{ }^{n+}$ cationic chains and isolated $\mathrm{ClO}_{4}^{-}$anions are interlinked together through these hydrogen bonding interactions, electrostatic interactions and van der Waals interactions to

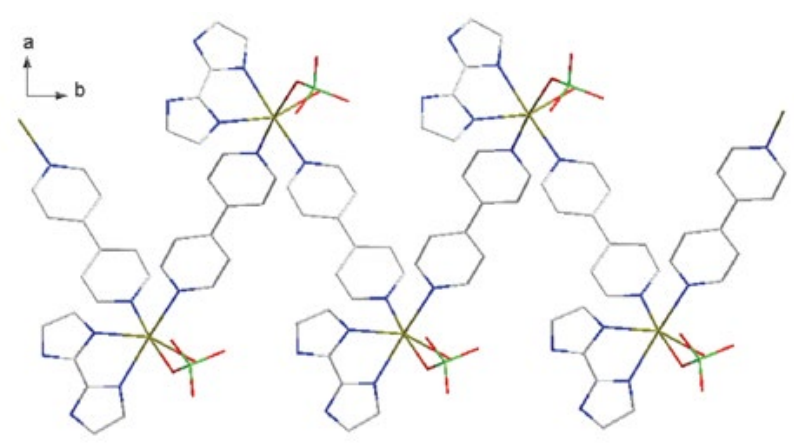

Figure 2. The 1-D zigzag chain structure of complex $\mathbf{1}$.

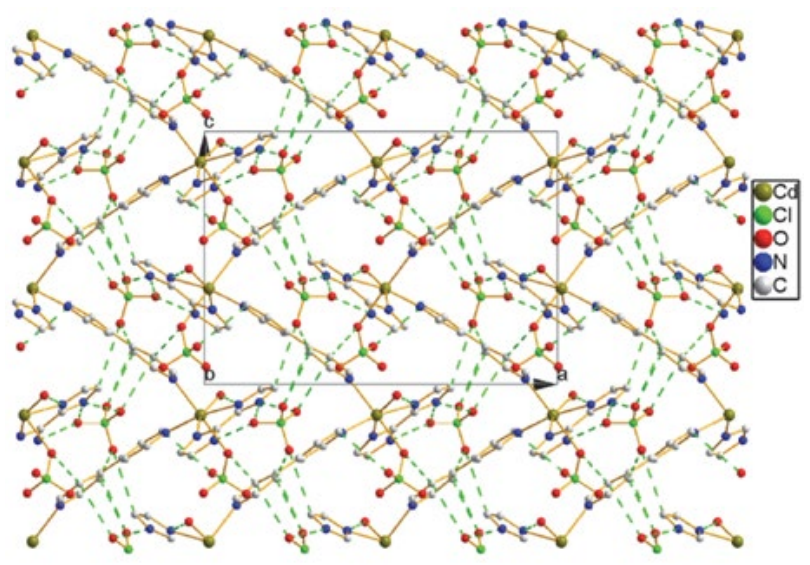

Figure 3. Packing diagram of complex 1 with the dashed lines representing the hydrogen bonding interactions. 
construct a three-dimensional (3-D) supramolecular structure as shown in Fig. 3. To the best of our knowledge, this is the first IIB complex containing both 4,4'-bipy and 2,2'-biim ligands, although a lot of IIB complexes with either 4,4'-bipy or 2,2'-biim as a ligand have been reported thus far. ${ }^{26-29}$

Table 3. Hydrogen bonding interactions

\begin{tabular}{|c|c|c|c|c|}
\hline$D-\mathbf{H} \cdots A$ & $D-\mathbf{H}, \AA$ & $\mathbf{H} \cdots A, \AA$ & $D \cdots A, \AA$ & $D-\mathbf{H} \cdots A,{ }^{\circ}$ \\
\hline $\mathrm{N} 1-\mathrm{H} 1 \mathrm{~B} \cdots \mathrm{O} 2^{\mathrm{ii}}$ & 0.86 & 2.38 & $3.169(6)$ & 153 \\
\hline $\mathrm{N} 1-\mathrm{H} 1 \mathrm{~B} \cdots \mathrm{O} 3^{\mathrm{ii}}$ & 0.86 & 2.31 & $3.058(5)$ & 146 \\
\hline $\mathrm{N} 3-\mathrm{H} 3 \mathrm{~A} \cdots \mathrm{O} 2^{\mathrm{ii}}$ & 0.86 & 2.07 & $2.905(5)$ & 162 \\
\hline $\mathrm{C} 8-\mathrm{H} 8 \mathrm{~A} \cdots \mathrm{O} 7^{\mathrm{ii}}$ & 0.93 & 2.54 & $3.328(6)$ & 142 \\
\hline $\mathrm{C} 10-\mathrm{H} 10 \mathrm{~A} \cdots \mathrm{O} 4^{\mathrm{iii}}$ & 0.93 & 2.57 & $3.298(6)$ & 136 \\
\hline
\end{tabular}

Symmetric codes: (ii) $-x,-y, 1 / 2+z$; (iii) $x, y, 1+z$.

In general, cadmium compounds can exhibit attractive photoluminescent properties and, therefore, they have potential application in the areas of light-emitting diodes, electrochemical displays, photoluminescent materials, sensors. ${ }^{30,31}$ Moreover, complexes containing 4,4'-bipy or 2,2'biim ligands can generally also show good photoluminescence due to the existence of their delocalized $\pi$ electrons. As a result, the title complex is expected to possess photoluminescent behavior. Based on these considerations, in the present work, we measured the photoluminescent properties of complex 1 using powder-like samples under room temperature. Fig. 4 gives the photoluminescent excitation and emission spectra of complex $\mathbf{1}$. As displayed in this figure, the photoluminescent emission spectra of complex 1 show a wide and intensive emission peak, while the photoluminescent excitation spectra show that the effective energy absorption mainly resides in the wavelength span of 250-430 $\mathrm{nm}$. The photoluminescent excitation spectra display a main peak at $424 \mathrm{~nm}$ and a shoulder at $355 \mathrm{~nm}$. When it was ex-

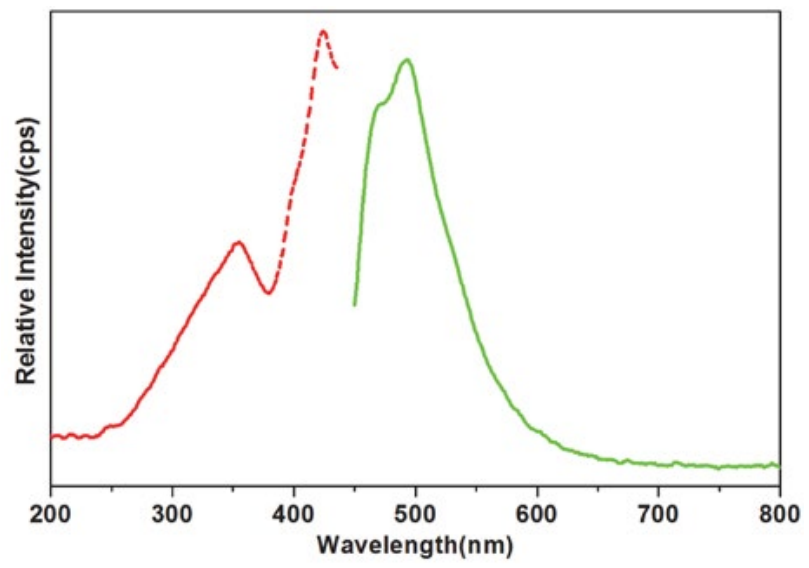

Figure 4. Photoluminescence spectra of 1 with the red and green lines representing excitation and emission spectra, respectively.

cited by the wavelength of $424 \mathrm{~nm}$, the photoluminescent emission spectra yield a strong emission peak at $493 \mathrm{~nm}$ in the green region of the spectrum. As a result, complex 1 could be a candidate material for green photoluminescence.

Trying to unveil the nature of the photoluminescence spectra of complex $\mathbf{1}$, we truncated ground state geometry from its single-crystal X-ray diffraction data set and carried out its theoretical calculation in light of the time-dependent density functional theory (TDDFT) based on this ground state geometry. The TDDFT investigation was performed with the B3LYP function and by virtue of the Gaussian03 software package. After successfully calculating, the theoretical electron-distribution diagrams were obtained using the ChemOffice Ultra 7.0 graphics program and the results are given in Fig. 5. It is easy to find out that the electron-density distribution of the singlet state of HOMO is totally resided at the coordinating perchlorate anion with an energy being of -0.213039 Hartrees; however, the electron-density population of the singlet state of the LUMO locates at the 4,4'-bipy ligand and the energy of

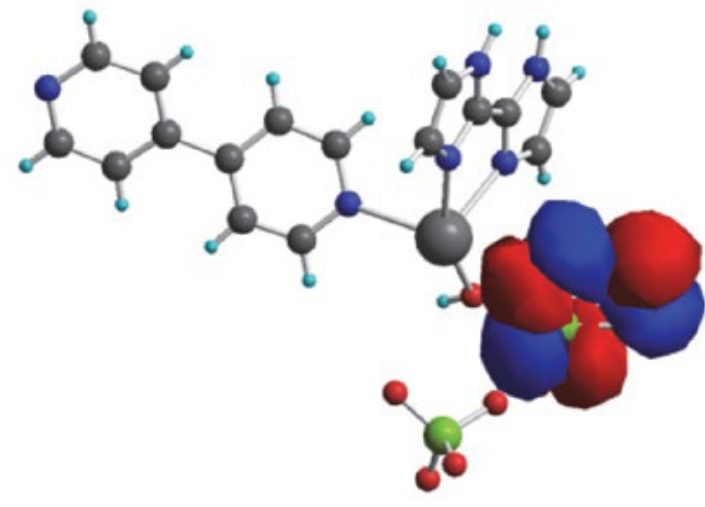

HOMO

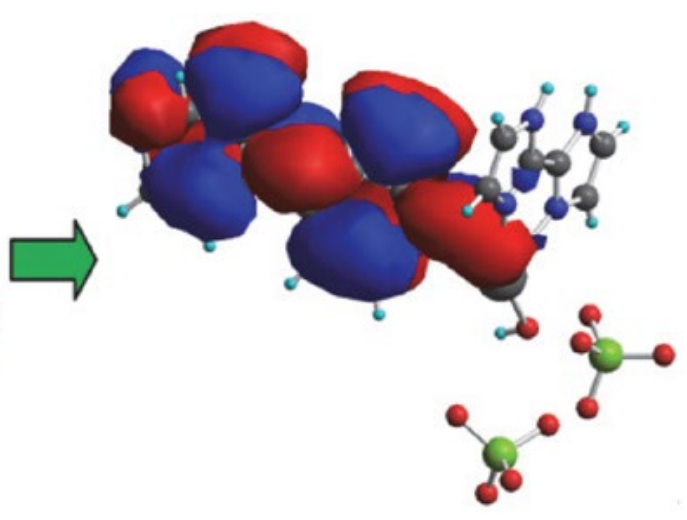

LUMO

Figure 5. The electron-density population of complex 1 . The isosurfaces correspond to the electronic density differences of $-10 e \mathrm{~nm}^{-3}(\mathrm{blue})$ and $+10 e \mathrm{~nm}^{-3}$ (red). 
the LUMO is calculated to be -0.122838 Hartrees. The energy difference between LUMO and HOMO is 0.090201 Hartrees that is small enough to allow the charge transfer from HOMO to LUMO. Based on these observation, it is proposed that the essence of the photoluminescence of complex 1 could be assigned to the ligand-to-ligand charge transfer (LLCT; from the HOMO of the perchlorate anion to the LUMO of the 4,4'-bipy ligand).

Cadmium compounds are well-known not only for their photoluminescent behaviors but also for their semiconductive properties and the latter enable them to be widely applied in military or civil areas. For example, HgCdTe, known as MCT, is one of the most famous military infrared detectors based on the semiconductive properties. Therefore, it could be worthy to measure the semiconductive properties of the title complex. Powder-like barium sulfate acts as a reference for $100 \%$ reflectance and finely-ground powder sample was coated on the surface of the barium sulfate. After measuring the solid-state UV/vis diffuse reflectance spectra, the data was treated carefully with the Kubelka-Munk function which is known as $\alpha / S=$ $(1-R)^{2} / 2 R$. With regard to this function, $\alpha$ means the absorption coefficient, $S$ refers to the scattering coefficient which is actually wavelength independent when the size of the particle is larger than $5 \mu \mathrm{m}$, and the $R$ is related to the reflectance. From the $\alpha / S v s$. energy gap diagram, the value of the optical band gap could be determined via extrapolating the linear portion of the absorption edges. In this way, the solid-state UV/vis diffuse reflectance spectra showed that complex $\mathbf{1}$ has a wide energy band gap of 3.25 $\mathrm{eV}$, as depicted in Fig. 6. As a result, complex 1 could be a possible candidate for the wide optical band gap semiconductors. The slow slope of the optical absorption edge of complex 1 suggests that it must be an indirect transition..$^{32}$ The energy band gap of $3.25 \mathrm{eV}$ of complex $\mathbf{1}$ is obviously larger than those of $\mathrm{CuInS}_{2}(1.55 \mathrm{eV})$, CdTe $(1.5 \mathrm{eV})$ and $\mathrm{GaAs}(1.4 \mathrm{eV})$, all of them are broadly applied as efficient photovoltaic materials. ${ }^{33,34}$

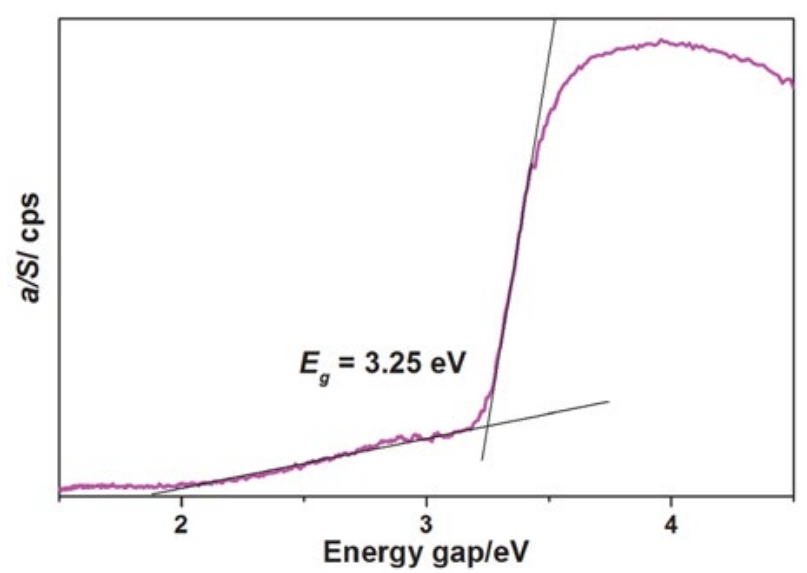

Figure 6. Solid-state UV/vis diffuse reflectance spectrum for complex 1.

\section{Conclusions}

In conclusion, a novel cadmium complex with mixed ligands has been synthesized and characterized by single-crystal X-ray diffraction. It exhibits a 1-D zigzag chain structure. It is the first cadmium complex with both 4,4'bipy and 2,2'-biim ligands. Powder photoluminescent characterization reveals that it displays an emission in the green region. TDDFT calculation revealed that the nature of the photoluminescence is originated from the ligand-to-ligand charge transfer (LLCT; from the HOMO of the perchlorate anions to the LUMO of the 4,4'-bipy ligand). A wide optical band gap of $3.25 \mathrm{eV}$ was determined by the solid-state UV/vis diffuse reflectance spectrum.

\section{Acknowledgements}

We gratefully acknowledge the financial support of the NSF of China (21361013, 21362015, 21461013, 51363009), Jiangxi Provincial Science and Technology Support Key Project (20152ACG70021), Jiangxi Provincial Natural Science Foundation (20142BAB205062, 20133ACB20010, 20132BAB203010), Jiangxi Provincial Department of Education's Item of Science and Technology (GJJ150761, GJJ14557, GJJ160745), Jinggangshan University Natural Science Item (JZ0813), the open foundation (ST201522007) of the Key Laboratory of Jiangxi Province for Persistant Pollutants Control and Resources Recycle (Nanchang Hangkong University), and the open foundation (20150019) of the State Key Laboratory of Structural Chemistry, Fujian Institute of Research on the Structure of Matter, Chinese Academy of Sciences.

\section{Supplementary Material}

Crystallographic data for the structure reported in this paper have been deposited with the Cambridge Crystallographic Data Centre as supplementary publication no. CCDC 1569870. Copies of the data can be obtained free of charge on application to CCDC, 12 Union Road, Cambridge CB2 1EZ, UK (fax: (44) 1223 336-033; e-mail: deposit@ccdc.cam.ac.uk).

\section{References}

1. Y.-M. So, W.-H. Leung, Coord. Chem. Rev. 2017, 340, 172197. DOI:10.1016/j.ccr.2016.12.009

2. C. C. Mokhtarzadeh, C. E. Moore, A. L. Rheingold, J. S. Figueroa, Angew. Chem. Int. Ed. 2017, 56, 10894-10899. DOI:10.1002/anie.201705877

3. M. Hoarau, C. Hureau, E. Gras, P. Faller, Coord. Chem. Rev. 2016, 308, 445-459. DOI:10.1016/j.ccr.2015.05.011

4. P. Zhang, J. M. Suárez, T. Driant, E. Derat, Y. Zhang, M. 
Ménand, S. Roland, M. Sollogoub, Angew. Chem. Int. Ed. 2017, 56, 10821-10825. DOI:10.1002/anie.201705303

5. A. J. Howarth, M. B. Majewski, M. O. Wolf, Coord. Chem. Rev. 2015, 282-283, 139-149. DOI:10.1016/j.ccr.2014.03.024

6. X.-X. Lu, Y.-H. Luo, C. Lu, X. Chen, H. Zhang, J. Solid State Chem. 2015, 232, 123-130. DOI:10.1016/j.jssc.2015.09.017

7. X.-F. Yang, M. Liu, H.-B. Zhu, Inorg. Chem. Commun. 2017, 83, 40-43. DOI:10.1016/j.inoche.2017.06.007

8. D. P. Malenov, G. V. Janjić, V. B. Medaković, M. B. Hall, S. D. Zarić, Coord. Chem. Rev. 2017, 345, 318-341.

DOI:10.1016/j.ccr.2016.12.020

9. P. Maślewski, K. Kazimierczuk, Z. Hnatejko, A. Dołęga, Inorg. Chim. Acta 2017, 459, 22-28. DOI:10.1016/j.ica.2017.01.014

10. M.-L. Wei, J.-H. Wang, Y.-X. Wang, J. Solid State Chem. 2013, 198, 323-329. DOI:10.1016/j.jssc.2012.10.025

11. M. Zhu, M.-T. Li, L. Zhao, K.-Z. Shao, Z.-M. Su, Inorg. Chem. Commun. 2017, 79, 69-73.

DOI:10.1016/j.inoche.2017.03.020

12. W.-T. Chen, J.-G. Huang, X.-G. Yi, Acta Chim. Slov. 2016, 63, 899-904. DOI:10.17344/acsi.2016.2897

13. L. N. Wang, L. Fu, J. W. Zhu,Y. Xu, M. Zhang, Q. You, P. Wang, J. Qin, Acta Chim. Slov. 2017, 64, 202-207.

DOI:10.17344/acsi.2016.3109

14. H. S. Mansur, A. A. P. Mansur, A. Soriano-Araújo, Z. I. P. Lobato, Green Chem. 2015, 17, 1820-1830.

DOI:10.1039/C4GC02072C

15. A. R. D. Voet, H. Noguchi, C. Addy, K. Y. J. Zhang, J. R. H. Tame, Angew. Chem. Int. Ed. 2015, 54, 9857-9860.

DOI:10.1002/anie.201503575

16. Rigaku, CrystalClear Version 1.3.5, Rigaku Corporation, 2002.

17. Siemens, SHELXTL ${ }^{T M}$ Version 5 Reference Manual, Siemens Energy \& Automation Inc., Madison, Wisconsin, USA, 1994.

18. P. Peng, F.-F. Li, V. S. P. K. Neti, A. J. Metta-Magana, L. Echegoyen, Angew. Chem. Int. Ed. 2014, 53, 160-163.

DOI:10.1002/anie.201306761

19. S. Konar, A. Jana, K. Das, S. Ray, J. A. Golen, A. L. Rheingold, S. K. Kar, Inorg. Chim. Acta 2013, 397, 144-151.

DOI:10.1016/j.ica.2012.12.003
20. J. Jin, X. Han, Q. Meng, D. Li, Y.-X. Chi, S.-Y. Niu, J. Solid State Chem. 2013, 197, 92-102. DOI:10.1016/j.jssc.2012.09.016

21. M. Hakimi, Z. Mardani, K. Moeini, F. Mohr, M. A. Fernandes, Polyhedron 2014, 67, 27-35. DOI:10.1016/j.poly.2013.08.065

22. J. A. Wilson, P. E. Kraft, R. L. LaDuca, Inorg. Chim. Acta 2013 , 404, 97-104. DOI:10.1016/j.ica.2013.04.027

23. P.-W. Liu, C.-P. Li, Y. Bi, J. Chen, J. Coord. Chem. 2013, 66, 2012-2022. DOI:10.1080/00958972.2013.797078

24. Y.-Y. Liu, J. Liu, J. Yang, B. Liu, J.-F. Ma, Inorg. Chim. Acta 2013, 403, 85-96. DOI:10.1016/j.ica.2013.03.009

25. X.-F. Wang, X.-Y. Yu, J.-K. Hu, H. Zhang, J. Coord. Chem. 2013, 66, 2118-2128. DOI:10.1080/00958972.2013.798654

26. X. Zhao, F. Liu, L. Zhang, D. Sun, R. Wang, Z. Ju, D. Yuan, D. Sun, Chem. Eur. J. 2014, 20, 649-652.

DOI: $10.1002 /$ chem. 201304146

27. S.-N. Zhao, S.-Q. Su, X.-Z. Song, M. Zhu,Z.-M. Hao, X. Meng, S.-Y. Song, H.-J. Zhang, Cryst. Growth Des. 2013, 13, 27562765. DOI:10.1021/cg3018387

28. W. Xu, J. Jiang, M. Pan, C. Su, Inorg. Chem. Commun. 2013, 31, 83-86. DOI:10.1016/j.inoche.2013.02.018

29. X. Zhang, G. Ma, F. Kong, Z. Yu, R. Wang, Inorg. Chem. Commun. 2012, 22, 44-47.

DOI:10.1016/j.inoche.2012.05.020

30. S. S. M. Rodrigues, D. S. M. Ribeiro, J. X. Soares, M. L. C. Passos, M. L. M. F. S. Saraiva, J. L. M. Santos, Coord. Chem. Rev. 2017, 330, 127-143. DOI:10.1016/j.ccr.2016.10.001

31. V. Kumar, K.-H. Kim, P. Kumar, B.-H. Jeon, J.-C. Kim, Coord. Chem. Rev. 2017, 342, 80-105.

DOI:10.1016/j.ccr.2017.04.006

32. F. Q. Huang, K. Mitchell, J. A. Ibers, Inorg. Chem. 2001, 40, 5123-5126. DOI:10.1021/ic0104353

33. P. Dürichen, W. Bensch, Eur. J. Solid State Inorg. Chem. 1997, 34, 1187-1198.

34. R. Tillinski, C. Rumpf, C. Näther, P. Duerichen, I. Jess, S. A. Schunk, W.Bensch,Z.Anorg. Allg. Chem. 1998, 624, 1285-1290. DOI:10.1002/(SICI)1521-3749(199808)624:8<1285::AIDZAAC1285>3.0.CO;2-5

\section{Povzetek}

$S$ hidrotermalno reakcijo smo sintetizirali nov kadmijev kompleks z različnimi ligandi, $\left\{\left[\mathrm{Cd}\left(2,2^{`}\right.\right.\right.$-biim $)\left(4,4^{`}-\right.$ bipy $)\left(\mathrm{H}_{2} \mathrm{O}\right)$ $\left.\left.\left(\mathrm{ClO}_{4}\right)\right]\left(\mathrm{ClO}_{4}\right)\right\}_{\mathrm{n}}(\mathbf{1})\left(2,2^{`}\right.$-biim = 2,2`'biimidazol; 4,4'-bipy = 4,4'-bipiridin), ter določili kristalno strukturo $\mathrm{z}$ monokristalno rentgensko difrakcijo. Rentgenska strukturna analiza razkriva, da kompleks 1 kristalizira $\mathrm{v}$ prostorski skupini $P n a 2_{1}$ ortorombskega kristalnega sistema $\mathrm{z}$ enodimenzionalnimi cikcak $\left[\mathrm{Cd}\left(2,2^{c} \text {-biim }\right)\left(4,4^{c} \text {-bipy }\right)\left(\mathrm{H}_{2} \mathrm{O}\right)\left(\mathrm{ClO}_{4}\right)\right]_{n}{ }^{n+} \mathrm{ka}^{-}$ tionskimi verigami in izoliranimi $\mathrm{ClO}_{4}^{-}$anioni. Analiza fotoluminiscenčnih lastnosti prahu kaže, da kompleks 1 emitira zeleno svetlobo. Izračuni na podlagi teorije časovno odvisnega gostotnostnega funkcionala (TDDFT) kažejo, da je vzrok za pojav fotoluminiscence $\mathrm{v}$ kompleksu $1 \mathrm{v}$ prenosu naboja $\mathrm{z}$ liganda na ligand (LLCT; od HOMO perkloratnega aniona k LUMO 4,4'-bipy liganda). S pomočjo UV/Vis difuzne reflektance v trdnem stanju je bil ugotovljen širok prepovedani pas velikosti $3.25 \mathrm{eV}$. 